\title{
THE ARTHUR D. LITTLE RESEARCH INSTITUTE
}

\begin{abstract}
THE annual report for 1960 of the Arthur D. Little Research Institute* records an average expansion since 1957 of about 20 per cent per annum. Sixty-five per cent of its income comes from industry and 35 per cent from Government and related agencies, about half its sponsors being British and European and the rest American. Practically all the Institute's work is classified as oriented fundamental research, and has so far been predominantly concerned with the chemistry of plant materials. The Biochemistry Section was established in 1960 to undertake the study of biochemical problems where newer techniques, such as starch-gel and high-voltage electrophoresis and paper and column chromatography with automatic densitometry, are already having their impact. Work has been initiated on the separation of the wheat gluten gel complex into its components.

The Organic Chemistry Section continued work on the polymerization of glucose and its derivatives, and already polyamides with viscosities comparable with those of nylon have been obtained using the new technique of interfacial polycondensation. In the work on the chemical modification of wood, a lowtemperature catalytic acetylation process gave wood of permanent shrinkage and only slightly improved dimensional stability. Promising results have been

* Arthur D. Little Research Institute. Annual Report for 1960. Pp. 44. (Inveresk, Midlothian: Arthur D. Little Research Institute, 1961.)
\end{abstract}

obtained by impregnating wood with monomers and polymerizing in situ, and attempts have been made to reduce flammability of wood by introducing nonleachable compounds containing phosphorus. Work was initiated on the release of corrosive volatile vapours from wood at high humidity and high ambient temperatures, that is, greater than $40^{\circ} \mathrm{C}$.. and also to explore the properties of ethylene sulphide.

In physical chemistry, the Polymer Section continued to study the bulk properties of polyolefins, particularly the kinetics of crystallization of polyethylene, with the view of obtaining a better understanding of the effect of crystal structure on the physical properties, and has shown that the initial crystallization behaviour depends markedly on molecular weight. Work was also commenced on the kinetics of the reaction between molten aluminium and water.

The Metallurgy Section completed a three-year study of corrosion involving the screening of 470 organic compounds, to ascertain any correlation between chemical structure and inhibitory power, and although no clear-cut correlation emerged, some compounds were found to favour the inhibition of corrosion of mild steel and cast iron in acid solution while others opposed inhibition. A study of the hydrogen embrittlement of certain steels is planned. A list of publications of the Institute is appended with abstracts of those published in 1960 .

\section{THE WOOL INDUSTRIES RESEARCH ASSOCIATION}

I addressing the forty-second annual general meeting of the Wool Industries Research Association on April 19, the chairman of the Association, Mr. B. A. Smith, after referring to the opening of the new Worsted Processing Block at Torridon on March 22 (see Nature, 190, 313; 1961) by the Right Hon. R. G. Menzies, stressed the need for more research and technical education in the industry. The Association was just ending a quinquennial period in which the grant from the Department of Scientific and Industrial Research had been based on $£ 170,000$ of industrial income; under the new $£ 70,000$ arrangements this grant would be $£ 59,000$ on $£ 170,000$ of industrial income, but with a further $£ 75$ for every $£ 100$ supplied by industry up to a total of $£ 25,000$, and Mr. Smith asked for support for any proposal in the near future for an increase in. levy.

The report of the director of research, Dr. A. B. D. Cassie, for $1960^{*}$ refers to progress in constructing an apparatus for the automatic quantitative analysis of mixtures of amino-acids by separating them on a cationic exchange-resin column, converting to copper complexes, and determining the copper content polarographically. Excellent results have been obtained in the automatic assay of basic amino-acids,

* Wool Industries Research Association. Report of the Director of Research for 1960 . (Publication No. 215.) Pp. 39. (Torridon
Headingley, Leeds: Wool Industries Research Association, 1961.) but citrate buffers cannot be used for chromato. graphy because of the formation of copper-citrate complexes, and new buffer systems are being developed for amino-zcid separation. Several protein components of oxidized wool have been isolated by percolating columns of the material with $5 M$ urea solution, gradually changing in $p \mathrm{H}$ from 3.0 to $5 \cdot 8$, and determinations by Sanger's method of the $\mathrm{N}$-terminal groups of the components isolated from wool following treatment with acid gave average chain-weights of 96,500 and 20,500 for component I and component III, respectively.

Search for a method of determining the moisture content of raw wool continued, and a general survey being made of the diffusion constants of a wide range of organic molecules, from toluene and benzyl alcohol to a non-ionic detergent of $\mathrm{mol}$. wt. 558, indicates that the mobility of a molecule in keratin depends more on its hydrophobic-hydrophilic balance than its size. Work completed on the breaking-time and dynamic elastic modulus of nylon confirms that changes in moisture content affect both the elastic properties and the strength of the structural elements as well as the internal viscosity.

Recent work has shown that at least one of the causes of yellowing of woollen yarn on storage is the presence in the olein of small amounts of polyunsaturated acids: linolenic acid causes permanent yellowing, but the effect of linoleic acid is less 
important, while pure oleic acid has little deleterious action. Laboratory and works trials have shown that the moth-proofing agent 'Dielmoth' can be applied to worsted yarn during normal bleaching processes, but the treated yarn had only poor washing fastness. Fabric construction has been shown to play an important part in the production of fabrics with durable pleats or creases.

\section{THE BENGUELA CURRENT}

$\mathrm{I}^{\mathrm{N}}$ 1953 two interesting articles appeared in Nature. The first was by Currie ${ }^{1}$ and described the process of upwelling in the Benguela current. He showed that in addition to the upwelling inshore, a convection cell develops at the edge of the continental shelf which separates the cold upwelled waters from the warm oceanic waters further out to sea. This line of demarcation is used in a recent report* to define clearly what is meant by the Benguela current : "We have restricted the use of the name Benguela current to the coastal circulation in which upwelling movements occur and have referred to the oceanic circulation as the "south-east trade wind drift'."

The second article was by Hart' and dealt with the preliminary results of the phytoplankton surveys. He stressed the distinction between oceanic species of the south-east trade-wind drift and the coastal forms in the rich upwelled waters. In the latter he introduced the new conception of ageing of upwelled water, by which was meant the succession of species as the characteristics of the water mass change.

In the present report the two authors have enlarged on these preliminary findings. New data on winds, surface drift, bottom topography, water temperatures, salinities, dissolved oxygen, phosphate and the species composition, density and distribution of the microplankton have been analysed and coordinated to form an impressive picture of the oceanography of the seas off south-west Africa.

After summarizing the results of earlier investigations, the two cruises of R.R.S. William Scoresby off south-west Africa are described. The first was in the southern autumn (March 3-14, 1950) and the second was in spring (September 21-October 12). They go on to show that the winds are the driving force behind the currents. Off the shelf, the southeast trades cause a drift which Defant ${ }^{3}$ has shown to be north-north-west, parallel to the coast. Nearer the coast and on the shelf itself, there are coastal winds which are mainly south-south-west and these induce a current away from the shore and upwelling results. Many charts and sections show that this upwelled water differs from the oceanic water in temperature, salinity, dissolved oxygen and phosphate concentration. In spite of complexities due to swirls and interlocking tongues of water, the dividing line lies approximately over the edge of the continental shelf. Moreover, the vertical sections show clearly that on this line the isotherms and isohalines above the $300-\mathrm{m}$. level have an upward kink and that water from the $200-300-\mathrm{m}$. level reaches the surface inshore. The kink in the isotherms is the result of the convection cell which separates the two water masses and is well illustrated in a section which shows the distribution of the anomaly of specific volume off the mouth of the Orange River during the spring survey when active upwelling was in progress. It is suggested that conditions in the Benguela current are similar to

* Discovery Reports, Vol. XXXI. The Benguela Current. By T. Joniversity Press, 1960.) Currie. those in upwelled waters off California where Sverdrup ${ }^{4}$ has described a similar convection cell.

The evidence that the upwelled water comes from the $200-300-\mathrm{m}$. level denies once and for all the vague idea that the Antarctic intermediate current is concerned, for the latter lies at the $600-800-\mathrm{m}$. level. The water at the $200-300-\mathrm{m}$. level is part of the South Atlantic central water and its origin is controversial. Possibly it is the result of sinking at the sub-tropical convergence. Off south-west Africa there is a general movement to north-north-west at this level, but there are also indications, based on admittedly slender evidence, of a southerly movement along the edge of the shelf. "It is postulated that this is a compensatory movement replacing the water which has been drawn up to the surface inshore and we have therefore called it the compensation current." Vertical sections of salinity, temperature and phosphate show no discrete body of water at this level, nor is the existence of this southerly current essential to the main argument, and I doubt its existence. Indeed, the distribution of the oxygen minimum layer in the South Atlantic shown in Fig. 47 is more readily understandable as a north-westerly drift of the products of decay from the highly productive areas off south-west Africa.

The second part of the report deals with the microplankton as sampled by N.50.V. nets. The bulk of the catch was diatoms and peridinians. After dealing with the vexed question of terminology in which the term 'panthallassic' is revived to cover species which at different times are both neritic and oceanic, the authors give a full list of the species identified and select from this the dominants for further discussion. Their distribution is charted and their density discussed in relation to distance from the shore. In broad outline they found a dense growth of chætocerids and some other neritic species in the area of upwelling, a scant growth of Planktoniella sol and other oceanic forms off the shelf and a poor flora of panthallassic species in between. It is stressed that the many differences between the spring and autumn surveys may not be purely seasonal effects but the result of ageing of upwelled waters: "The more extensive coastal production in autumn (survey 1) with numerous resting spores of the dominant chætocerids is thought to represent a late stage in the succession of waters earlier enriched by upwelling . . . the succession may be reperted several times annually." This section ends with valuable notes on the ecology and distribu. tion of the more important species and most ecolog. ists would agree with the final warning that it is not the presence or absence of a particular species which defines a particular water mass but the differing proportions of the species within them. Statistical mothods for the discrimination of floristic groups are now being developed.

Finally, the authors come to the controversial question of the mass mortality of fish in the Walvis Bay area and the cause of the ancerobic deposits which extend along the shelf for some 400 miles. 